\title{
TFE3/PRCC Fusion Protein
}

National Cancer Institute

\section{Source}

National Cancer Institute. TFE3/PRCC Fusion Protein. NCI Thesaurus. Code C99392.

A fusion protein encoded by the TFE3/PRCC fusion gene. This protein is comprised of the extreme $\mathrm{N}$-terminal amino acids of the transcription factor $\mathrm{E} 3$ protein fused to the $\mathrm{C}$ terminal half of proline-rich protein PRCC. 